\title{
Functional and structural specific roles of activity-driven BDNF within circuits formed by single spiny stellate neurons of the barrel cortex
}

\author{
Qian-Quan Sun*, Zhi Zhang, June Sun, Anand S. Nair, Dan P. Petrus and Chunzhao Zhang
}

Department of Zoology and Physiology, University of Wyoming, Laramie, WY, USA

\section{Edited by:}

Rakez Kayed, University of Texas Medical Branch, USA

\section{Reviewed by:}

Xiaoming Jin, Indiana University Purdue University Indianapolis, USA Oscar E. Ruiz, University of Texas Medical Branch Galveston, USA Li-Rong Shao, Johns Hopkins

University School of Medicine, USA

\section{*Correspondence:}

Qian-Quan Sun, Department of Zoology and Physiology, University of Wyoming, Laramie, WY 82071, USA e-mail: neuron@uwyo.edu

\begin{abstract}
Brain derived neurotrophic factor (BDNF) plays key roles in several neurodevelopmental disorders and actions of pharmacological treatments. However, it is unclear how specific BDNF's effects are on different circuit components. Current studies have largely focused on the role of BDNF in modification of synaptic development. The precise roles of BDNF in the refinement of a functional circuit in vivo remain unclear. Val66Met polymorphism of BDNF may be associated with increased risk for cognitive impairments and is mediated at least in part by activity-dependent trafficking and/or secretion of BDNF. Using mutant mice that lacked activity-driven BDNF expression (bdnf-KIV), we previously reported that experience regulation of the cortical GABAergic network is mediated by activity-driven BDNF expression. Here, we demonstrate that activity-driven BDNF's effects on circuits formed by the layer IV spiny stellate cells are highly specific. Structurally, dendritic but not axonal morphology was altered in the mutant. Physiologically, GABAergic but not glutamatergic synapses were severely affected. The effects on GABA transmission occurs via presynaptic alteration of calcium-dependent release probability. These results suggest that neuronal activity through activity-driven BDNF expression, can selectively regulate specific features of layer IV circuits in vivo. We postulate that the role of activitydependent BDNF is to modulate the computational ability of circuits that relate to the gain control (i.e., feed-forward inhibition); whereas the basic wiring of circuits relevant to the sensory pathway is spared. Gain control modulation within cortical circuits has broad impact on cognitive processing and brain state-transitions. Cognitive behavior and mode is determined by brain states, thus the studying of circuit alteration by endogenous BDNF provides insights into the cellular and molecular mechanisms of diseases mediated by BDNF.
\end{abstract}

Keywords: variance-mean analysis, neurotrophin, dendritic spine, axonal arborizations, presynaptic

\section{INTRODUCTION}

Brain derived neurotrophic factor (BDNF) plays key roles in several neurodevelopmental and neuropsychiatric disorders including Rett Syndrome (Chang etal., 2006; Li and Pozzo-Miller, 2014), schizophrenia (Durany and Thome, 2004; Lu and Martinowich, 2008), major depression disorder (MDD; Martinowich et al., 2007), attention deficit hyperactivity disorder (ADHD; Kebir et al., 2009; Caylak, 2012), and actions of pharmacological treatments (Longo and Massa, 2013; Ninan, 2014) in these diseases. A consensus of the role of BDNF in neurodevelopmental disorders is related to its role in the regulation of synaptic maturation within critical brain areas (Li and Pozzo-Miller, 2014). Current studies have largely focused on the role of BDNF in modification of synaptic development (Lu, 2003; English et al., 2012). The precise roles of BDNF in the refinement of an entire functional circuit in vivo remain unclear.

The refinement of a neural circuit during development depends on a dynamic process of axonal and dendritic branching that leads to changes in synaptic connectivity. Neuronal activities play a crucial role in neural circuit refinement. It has been proposed that
BDNF acts as a modulator, rather than a direct mediator of activity during the morphological development of neural circuits (CohenCory, 1999). The transcription of the $b d n f$ gene is mediated by nine discrete promoters; each driving a unique $5^{\prime}$ exon (exons I-VIII) that is spliced onto the common $3^{\prime}$ coding exon (exon IX) to synthesize the same pre-, pro- BDNF proteins (Aid et al., 2007). These promoters drive activity-, epigenetic-, or hormonal -dependent BDNF expressions. Single nucleotide polymorphism in BDNF val66met allele is implicated with increased risk for schizophrenia, and cognitive impairments and is mediated at least in part by activity-dependent trafficking and/or secretion of BDNF (Lu and Martinowich, 2008; Li and Pozzo-Miller, 2014). Although extensive knowledge has been accumulated regarding the roles of BDNF signaling at the organismal and regional tissue level, relatively little is known about BDNF expression being driven by different promoters (e.g., activity-dependent endogenous BDNF), in playing a specific roles in the formation of a functional circuit in vivo. There are examples where BDNF can differentially modulate axonal and dendritic arborizations within a single neuronal population (Kang and Schuman, 1996; Lom and Cohen-Cory, 1999). However, it is 
unclear if BDNF driven by a specific promoter has similar effects. The exact roles of activity-driven BDNF expression in the synapse and circuit specific modulations remain elusive. BDNF's effects are spatially confined within single neurons, or even different subcellular domains (Horch and Katz, 2002; Horch, 2004; English et al., 2012). An understanding of local signaling functions at the level of single neurons for specific BDNF promoters is essential in defining its roles in modulating neural circuitry.

We sought to contribute to this area by using layer IV circuits formed by spiny stellate cells within the mouse whisker-barrel system, the first sensory processing unit within the primary sensory cortex. In this circuit, the contribution of cell types and their different synaptic components to sensory perception/transmission can be clearly explained. Using a strain of genetically modified mice $\left(\mathrm{KIV}^{-/-}\right)$that exhibits relatively normal basal expression but severely reduced activity-driven BDNF expression in the cortex (Sakata et al., 2009), we have recently demonstrated a critical role of activity-driven BDNF expression in the activity-dependent modulation of GABAergic transmissions (Jiao et al., 2011). The present study examines the structural (axonal vs. dendritic) and synaptic specific (GABAergic vs. glutamatergic) properties of layer IV circuits in the $\mathrm{KIV}^{-/-}$mice. In this study, we focused on spiny stellate cells within the mouse somatosensory cortex, in which previous studies have demonstrated circuit-wide changes in response to the manipulation of sensory experiences (Feldman et al., 1999; Feldman and Brecht, 2005; Holtmaat et al., 2006; Feldmeyer etal., 2013). Our results indicate that the actions of activity-driven BDNF are highly specific to the presynaptic organization of GABAergic synapses and dendrites, particularly dendritic spines, but not the formation of intracortical glutamatergic axonal arborizations and synapses. Thus, we postulate that the role of activity-driven BDNF expression is to specifically modulate the computational ability of circuits that relate to gain control; rather than the basic wiring of the circuits. These results support the idea that BDNF signaling at the level of individual neurons is highly specific, and understanding the specificity of BDNF is central to understanding how BDNF is involved in the modulation of development, maintenance, and plasticity of neural circuitry and neural basis underlying neurodevelopmental disorders involving BDNF.

\section{MATERIALS AND METHODS}

All experiments using mice were approved by the IACUC committee of the University of Wyoming.

\section{BRAIN SLICE PREPARATIONS, ELECTROPHYSIOLOGICAL RECORDINGS}

Mice were deeply anesthetized with isoflurane and decapitated. The brains were quickly removed and placed into cold $\left(\sim 4^{\circ} \mathrm{C}\right)$ oxygenated slicing medium containing (in $\mathrm{mM}$ ): $2.5 \mathrm{KCl}, 1.25$ $\mathrm{NaH}_{2} \mathrm{PO}_{4}, 10.0 \mathrm{MgCl}_{2}, 0.5 \mathrm{CaCl}_{2}, 26.0 \mathrm{NaHCO}_{3}, 11.0$ glucose, and 234.0 sucrose. TC slices were prepared according to methods described by Agmon and Connors (1991). Tissue slices (300$400 \mu \mathrm{m}$ ) were cut using a vibratome (TPI, St. Louis, MO, USA), transferred to a holding chamber, and incubated $\left(35^{\circ} \mathrm{C}\right)$ for at least $1 \mathrm{~h}$. Individual slices were then transferred to a recording chamber, fixed to a modified microscope stage, and allowed to equilibrate for at least $30 \mathrm{~min}$ before recording. Slices were min- imally submerged and continuously superfused with oxygenated physiological saline at the rate of $4.0 \mathrm{ml} / \mathrm{min}$. The physiological perfusion solution contained (in $\mathrm{mM}$ ): $126.0 \mathrm{NaCl}, 2.5 \mathrm{KCl}, 1.25$ $\mathrm{NaH}_{2} \mathrm{PO}_{4}, 1.0 \mathrm{MgCl}_{2}, 2.0 \mathrm{CaCl}_{2}, 26.0 \mathrm{NaHCO}_{3}$, and 10.0 glucose. Solutions were gassed with $95 \% \mathrm{O}_{2} / 5 \% \mathrm{CO}_{2}$ to a final $\mathrm{pH}$ of 7.4 at a temperature of $35 \pm 1^{\circ} \mathrm{C}$. The method for identification of the barrel subfield in living TC slices was described in earlier studies (Sun et al., 2006). A low-power objective $(2.5 \times)$ was used to identify barrels and thalamic nuclei, and a high-power water immersion objective $(60 \times)$ with Nomarski optics and infrared video was used to visualize individual neurons. Recording pipettes were pulled from capillary glass obtained from World Precision Instruments (M1B150F-4), using a Sutter Instrument P80 puller, and had tip resistances of 2-5 $\mathrm{M} \Omega$ when filled with the intracellular solutions below. A Multi-Clamp 700B amplifier (Axon Instruments, Foster City, CA, USA) was used for voltage-clamp and current clamp recordings. Patch pipette saline was modified according to Brecht and Sakmann (2002) and composed of (in mM): $100 \mathrm{~K}$-gluconate (or Cs-gluconate for IPSC recordings), 10.0 phosphocreatine-Tris, 3.0 $\mathrm{MgCl}_{2}, 0.07 \mathrm{CaCl}_{2}$, 4 EGTA, 10.0 HEPES, 4.0 $\mathrm{Na}_{2}$-ATP, and 1.0 Na-GTP, pH adjusted to 7.4 and osmolarity adjusted to $280 \mathrm{mOsm}$. Neurobiotin (0.5\%; Vector Labs) was added to the patch pipette solution. Data were accepted for analysis when access resistance in whole-cell recordings ranged from 15 to $35 \mathrm{M} \Omega$, and was stable ( $<25 \%$ change) during the recording. The resting membrane potential and the resting input resistance of the cell was also monitored to ensure a stable baseline recording. Current and voltage-clamp protocols were generated using PCLAMP9.2 software (Axon Instruments). A sharpened bipolar tungsten electrode, placed at $\sim 200 \mu \mathrm{m}$ away from recorded cells in the cortical layer IV, was used to activate intracortical fibers. eEPSCs were evoked in the presence of a cocktail ACSF solution containing $\mathrm{GABA}_{\mathrm{A}}$ antagonist picrotoxin $(50 \mu \mathrm{M})$ and low concentration of AMPA/kainate receptor antagonist 2,3-dihydro-6-nitro-7-sulfamoyl-benzo (F) quinoxaline (NBQX; $0.05 \mu \mathrm{M})$ to reduce excitation and prevent hyperexcitability (Kumar and Huguenard, 2003). Evoked EPSCs events were detected using Clampfit ${ }^{\circledR}$ event detection function with either 'threshold detection' or 'template detection' method.

\section{CHEMICALS}

AMPA antagonist GYKI 52466 hydrocloride, [1-(4-aminophenyl)4-methyl-7, 8-methylenedioxy-5H-2, 3-benzodiazepine] (SigmaAldrich, St. Louis, MO 63178, USA); 2,3-dihydro-6-nitro-7sulfamoyl-benzo $(\mathrm{F})$ quinoxaline (NBQX, Tocris, Ellisville, MO 63021, USA), DL-AP5 (Tocris), Picrotoxin (Tocris).

\section{VARIANCE-MEAN (V-M) ANALYSIS}

Variance-mean (V-M) analysis was conducted based on Oleskevich et al. (2000). Briefly, Synaptic events were evoked in different extracellular $\mathrm{Ca}^{2+} / \mathrm{Mg}^{2+}$ ratios (Silver et al., 1998, 2003; DiGregorio et al., 2002; Lawrence and McBain, 2003). Although there is a small differences in the concentration of the divalent cation, this is in sufficient to cause significant changes in the excitabilities (Hanck and Sheets, 1992). Next three parameters were used to describe synaptic function: the probability of vesicle release (Pr); the mean amplitude of the synaptic response to a vesicle of 
release $(\mathrm{Qw})$; and the number of release sites $(\mathrm{N})$. These parameters were obtained from the relationship between the variance and the mean of a post-synaptic amplitude recorded under various release probability conditions (Silver et al., 1998; Reid and Clements, 1999). When the V-M plot showed a typical parabolic plot $\mathrm{y}=\mathrm{Ax}-\mathrm{Bx}^{2}$ (1). The following two equations were used to calculate the average synaptic parameters: $\mathrm{Q}_{\mathrm{W}}=\mathrm{A} /\left(1+\mathrm{CV}_{\mathrm{I}}^{2}\right)(2)$; $\mathrm{P}_{\mathrm{rw}}=\mathrm{X}(\mathrm{B} / \mathrm{A})\left(1+\mathrm{CV}_{\mathrm{I}}^{2}\right)(3)$; and $\mathrm{N}_{\min }=1 / \mathrm{B}(4)$. When the release probability was low $(<0.3)$, the $\mathrm{V}-\mathrm{M}$ relationship was approximately linear, then the plot was analyzed with the linear equation of $Y=A x(5)$. This would permit an estimation of $Q w$ using equation (2), however, $\mathrm{P}_{\mathrm{rw}}$ and $\mathrm{N}_{\min }$ could not be estimated under this conditions.

\section{NEURONAL RECONSTRUCTION AND MORPHOMETRIC ANALYSIS}

Individual spiny stellate cells were labeled via intracellular loading neurobiotin during a 30-60 min whole-cell recording session. Brain slices $(350 \mu \mathrm{m})$ were subsequently histologically processed and mounted onto microscopy slides using methods described earlier (Young and Sun, 2009). The dendritic and axonal arbors of each spiny stellate cell were digitally traced using Neurolucida ${ }^{\circledR}$ under 100X oil-immersion objectives. Standard morphometric analysis (e.g., Sholl analysis, polar histogram) was conducted using Neurolucida Explorer ${ }^{\circledR}$ program, as described earlier (Young and Sun, 2009). Shrinkage related errors was not corrected.

\section{IMMUNOHISTOCHEMISTRY}

Brains were post-fixed after perfusion in $4 \%$ paraformaldehyde at $4^{\circ} \mathrm{C}$ overnight, cryoprotected in $30 \%$ sucrose for 2 days, frozen, and cut into $30 \mu \mathrm{m}$ thick cryostat sections. Free-floating sections were then stained for antibody-DAB as follows: sections were rinsed in PBS, incubated for $30 \mathrm{~min}$ in $0.5 \% \mathrm{H}_{2} \mathrm{O}_{2}$ in PBS, 2 min $\times 10$ min PBS washes, incubated for $2 \mathrm{~h}$ at room temperature in PBS with $0.3 \%$ Triton X-100, 0.05\% Tween, and $4 \%$ normal goat serum, and incubated overnight at $4{ }^{\circ} \mathrm{C}$ in PBS containing $0.2 \%$ Triton $\mathrm{X}-100$ and primary antibodies directed against: BDNF (1:500, Santa Cruz Biotechnology, sc546). Sections were then rinsed two times in PBS, incubated at room temperature for $90 \mathrm{~min}$ in PBS containing biotinylated goat anti-rabbit IgG (Vector labs), and finally incubated overnight at $4^{\circ} \mathrm{C}$ in Vectastain $\mathrm{ABC}$ kit (Vector Labs). Sections were then rinsed two times in PBS, developed in $50 \mathrm{mM}$ TBS containing $0.04 \%$ 3,3'-diaminobenzidine tetrahydrochloride (DAB, Sigma, St. Louis, MO, USA) and $0.012 \% \mathrm{H}_{2} \mathrm{O}_{2}$ washed two times with TBS, mounted onto glass slides, dehydrated, cleared, and coversliped. 3-D neuron models were reconstructed from stained cells using the Neurolucida system (MicroBrightField Inc., Williston, VT, USA) and a bright-field light microscope (Carl Zeiss MicroImaging Inc., Thornwood, NY, USA). Reconstructed neurons were quantitatively analyzed with NeuroExplorer (MicroBrightField Inc.).

\section{MOUSE BREEDING AND GENOTYPING}

The $\mathrm{KIV}^{+/-}$mice were crossed again to generate F2 homozygous $\mathrm{KIV}^{-/-}$and litter mate wild-type $\mathrm{KIV}^{+/+}$mice. Mouse genotyping methods were described earlier by Sakata et al. (2009).

\section{STATISTICS}

Upon group divisions, data was compared across groups using $t$-test, and/or single factor analysis of variances (one way-ANOVA) tests, followed by Tukey's HSD test in order to determine intergroup significance. $p<0.05$ was considered to be significantly different. In some experiments, $t$-test or Kolmogorov-Smirnov test was used as well.

\section{RESULTS}

Activity-driven BDNF-expression is abolished in the prefrontal cortex, hippocampus, and neocortex in the $\mathrm{KIV}^{-/-}$mice (Sakata et al., 2009). To further confirm this in the barrel cortex, we applied kainic acid (KA) in vivo $(30 \mathrm{mg} / \mathrm{Kg})$. Within the first hour of application, four out five treated animals developed seizures evolving into recurrent generalized convulsions and were used for histology experiments. The mice were euthanized at $4 \mathrm{~h}$ post-treatment, and BDNF level was assessed using immunohistochemistry (Figure 1A). In wild-type mice, KA significantly increased BDNF protein levels in both the hippocampus dentate gyrus (DG) area and in the barrel field (BF). In contrast, KA did not increase BDNF levels in these two areas in the $\mathrm{KIV}^{-/-}$ mice (Figure 1A3). These results indicated that activity-driven BDNF expression in the forebrain is abolished in the $\mathrm{KIV}^{-/-}$ mice. We then examined the anatomical remodeling occurring within the $\mathrm{BF}$ of the $\mathrm{KIV}^{-/-}$mice. Flattened tangential cortical slices were prepared for cytochrome-C staining to label the $\mathrm{BF}$ (Wong-Riley and Welt, 1980). The entire BF was reconstructed using Neurolucida ${ }^{\circledR}$ and analyzed using Neurolucida Explorer ${ }^{\circledR}$ (e.g., Figure 1B). Our results showed that there was a significant increase in the size of individual barrels within the major mystacial whisker barrels of $\mathrm{KIV}^{-/-}$mice $(p<0.01$, Figure 1C), but the barrel/septum ratio was unchanged (Figure 1D). Therefore, we conclude that the development and maintenance of major anatomical organization in the BF does not require activity-driven BDNF.

\section{DENDRITIC MORPHOLOGY}

The morphological analysis was based on 44 neurobiotin labeled intact layer IV spiny stellate cells, which consisted of 25 wild-type neurons $\left(\mathrm{KIV}^{+/+}\right)$and 19 mutant neurons $\left(\mathrm{KIV}^{-/-}\right)$. Cells with truncated dendrites were removed from the analysis. Spiny stellate cells were identified based on enriched dendritic spines and the absence of apical dendrites extending out of layer IV into supragranular layers (Staiger et al., 2004). We found that the dendritic morphology between the wild-type and mutant spiny stellate neurons was different in several ways. (1) The total number (Table 1) and density of spines on each dendrite (Figure 2) were significantly reduced (Table 1). (2) While the dendritic branching measured by the total number of intersections was unchanged, the total dendritic length was significantly reduced (Figure 2B2; Table 1). The distribution of spines along the dendrites of spiny stellate cells showed a linear correlation with dendritic location: distal dendrites had far more spines than proximal dendrites. The slope of this linear correlation was reduced in the mutant (Figure 2B4). As a result, the reduction in dendritic spines was positively correlated with dendritic length, i.e., distal dendritic spines are reduced the most in the mutant (Figure 2B5). 
A1

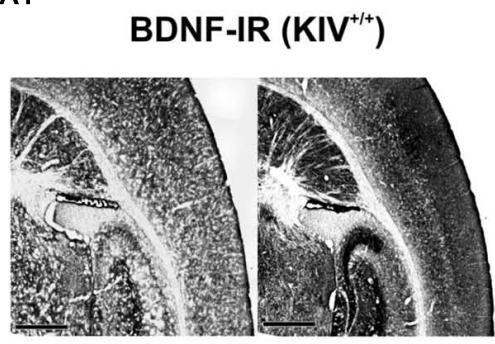

control

KA-treated
A2

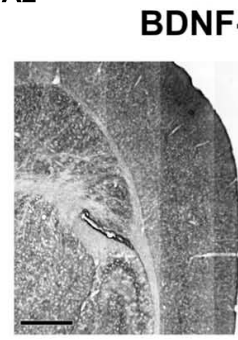

control
R $\left(\mathbf{K I V}^{+}\right)$

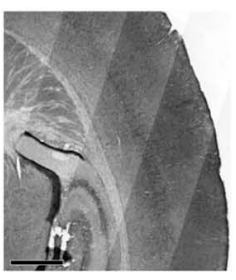

KA-treated
A3

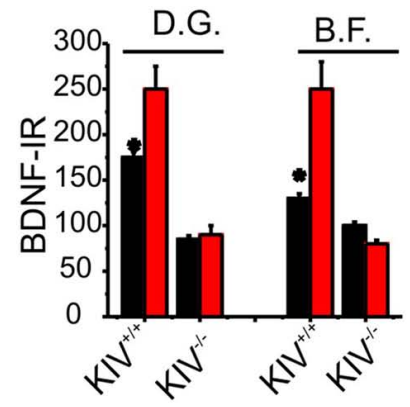

B1
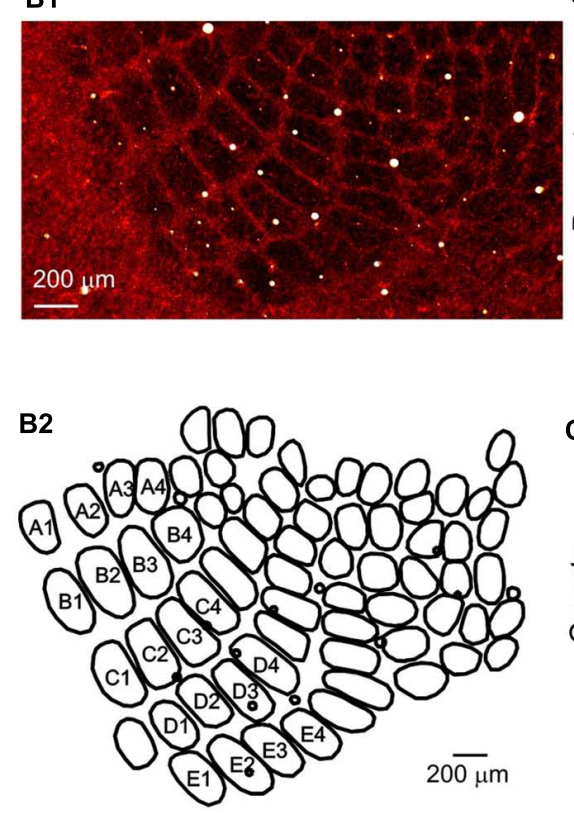

C1

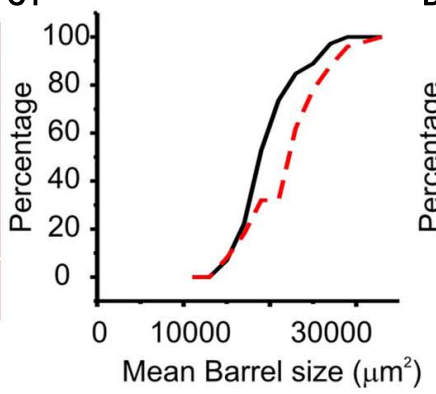

D1

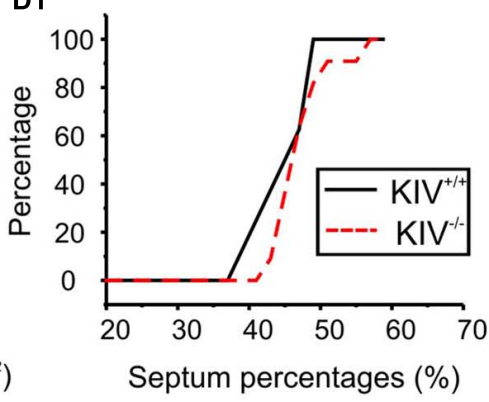

C2

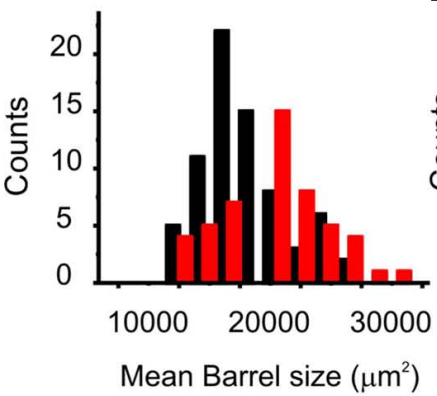

D2

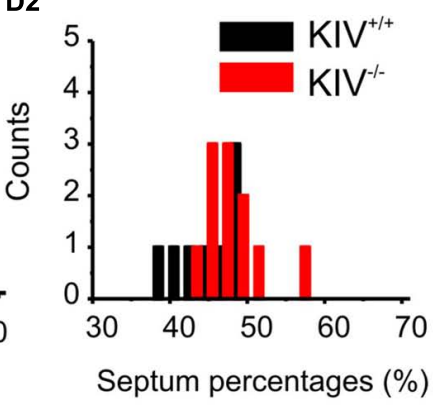

FIGURE 1 | Intact barrel structure with reduced activity-driven expression of BDNF in KIV-/- mice. (A) Photograph of BDNF-IR in thalamocortical sections of kainic acid treated (right) vs. control (left) wild-type (A1) and mutant (KIV-/-, A2) mice. (A3) the intensity of BDNF-IR was measured along lines across the barrel field (BF) and hippocampus dentate gyrus area (DG), respectively. $n=4$ mice in each group. Scale bars: $1 \mathrm{~mm}$. (B) Photograph of cytochrome-C stained BF in a flattened tangential section across layer IV of somatosensory cortex of wild-type mice (B1). The BF was re-constructed using Neurolucida ${ }^{\circledR}$, from which the morphometric data of BF was analyzed (B2). (C) The size of individual barrels within the primary mystacial BF (PMBF A1 though E4) was significantly larger in the mutant, $N=4$ in each group (C). (D) In contrast, the septum percentage within PMBF did not show significant differences. The measurements were made from 6 pairs of littermate control $(n=6)$ and mutant $(n=6)$ mice, respectively.
The majority of wild-type spiny stellate cells showed an asymmetric dendritic branching pattern: the distribution of dendrites confined within a barrel and the soma was located near the barrel border (Staiger et al., 2004; Egger et al., 2008). This asymmetric distribution of dendritic arbors correlate with the experience-dependent refinement process (Fox and Wong, 2005). Using a method described earlier by Egger et al. (2008), we examined if dendritic asymmetry was affected in the mutants. Indeed, there were significant reductions in asymmetry in the mutant neurons, with a higher percentage of cells showing reduced asymmetry (Figure 3; Table 1). Thus, the dendritic morphology of spiny stellate cells was significantly affected by the disruption of activity-driven BDNF expression, suggesting the maintenance of normal dendritic morphology and spine density requires activity-driven BDNF. Basal level of BDNF expression is insufficient to achieve this role.

\section{AXONAL ARBORS}

Intracortical axonal collaterals between layer IV cells contribute profusely to the excitatory synaptic inputs in spiny stellate cells (Feldmeyer etal., 1999). The morphological analysis of axonal arbors was based on 31 neurobiotin labeled, relatively intact layer IV spiny stellate cells. These consisted of 9 out of 21 wild-type neurons $\left(\mathrm{KIV}^{+/+}\right)$and 9 out of 10 mutant neurons $\left(\mathrm{KIV}^{-/-}\right)$ that were located at least $100 \mu \mathrm{m}$ below the surface of a $350 \mu \mathrm{m}$ 
Table 1 | Structural analysis of dendrites between wild-type and $\mathrm{KIV}^{-/-}$spiny stellate cells.

\begin{tabular}{|c|c|c|c|c|c|c|c|c|c|c|}
\hline & Qty & Nodes & Ends & Spines & $\begin{array}{l}\text { Length } \\
(\mu \mathrm{m})\end{array}$ & $\begin{array}{l}\text { Mean } \\
\text { length }\end{array}$ & $\begin{array}{l}\text { Surface } \\
\left(\mu \mathrm{m}^{2}\right)\end{array}$ & $\begin{array}{l}\text { Volume } \\
\left(\mu \mathrm{m}^{3}\right)\end{array}$ & $\begin{array}{l}\text { Polar angle } \\
\text { (after fan in) }\end{array}$ & $\begin{array}{l}\text { Polarized } \\
\text { cells } \\
(\text { yes }=1 \text {, } \\
\text { no }=0 \text { ) }\end{array}$ \\
\hline $\mathrm{KIV}^{+/+}(n=25)$ & $4.5 \pm 0.3$ & $23.1 \pm 1.4$ & $28.0 \pm 1.4$ & $488.4 \pm 64$ & $1818.6 \pm 90$ & $438.1 \pm 32$ & $3724.0 \pm 281$ & $1691.4 \pm 86$ & $126.9 \pm 6.8$ & $0.9 \pm 0.1$ \\
\hline $\begin{array}{l}\mathrm{KIV}^{-/-} \\
(n=19)\end{array}$ & $4.4 \pm 0.0$ & $18.9 \pm 0.1$ & $239 \pm 0.25$ & $288.1 \pm 42$ & $1527.3 \pm 96$ & $384.0 \pm 37$ & $2828.8 \pm 244$ & $4457.3 \pm 56$ & $154.2 \pm 8.5$ & $0.5 \pm 0.1$ \\
\hline$p$ value & 0.8 & 0.1 & 0.2 & 0.04 & 0.01 & 0.2 & 0.01 & 0.03 & 0.04 & 0.01 \\
\hline
\end{tabular}

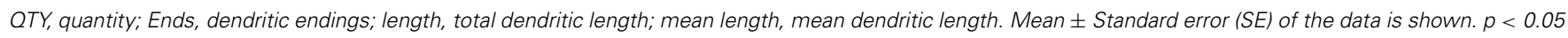
is considered statistically significant.

brain slice. The axonal arbors of both the mutant and wild-type spiny stellate cells showed typical patterns as previously described (Staiger etal., 2004; Egger etal., 2008). Briefly, the main stem of axons originated from the basal direction of the soma and extended toward the white matter. Within layer IV, the main stem of axons gave rise to abundant recurrent collaterals that centered on the barrels and extended to layer II/III barrels (Figure 4A). Cells with truncated axonal arbors, i.e., severe deviation from the typical axonal morphology, were removed from analysis. The morphometric data and Sholl analysis showed that there were no significant differences in either aspects of axonal morphologies, which include both the total length and the branching patterns (Table 2; Figures 4B,C). Therefore, in contrast to the dendrites, the morphology of axonal arbors of spiny stellate cells is independent of the activity-driven BDNF expression. The basal level of BDNF expression is therefore sufficient to the development and maintenance of intact axonal arbors in these cells.

\section{GABAergic TRANSMISSION}

We previously reported the disturbance of excitation-inhibition (E-I) balance in the $\mathrm{KIV}^{-/-}$mice (Jiao et al., 2011). To further understand how specific synapses are affected and the underlying synaptic mechanisms, we compared GABAergic transmissions within spiny stellate cells from wild-type and $\mathrm{KIV}^{-/-}$mice. Paired recordings were initially made from wild-type mice. The unitary IPSCs (uIPSCs) onto spiny stellate cells showed a strong pairedpulse depression that was reduced by calcium channel blocker cadmium (100 $\mu \mathrm{M}$, Figure 5A2), suggesting that inhibitory synapses were high release probability synapses (Xu-Friedman and Regehr, 2000; Silver et al., 2003). Next, evoked IPSCs (eIPSCs) were induced by an extracellular tungsten stimulating electrode located near the recorded cells $(<100 \mu \mathrm{m})$, in the presence of a cocktail solution containing NBQX $(10 \mu \mathrm{M})$ and AP-5 $(100 \mu \mathrm{M})$ to block AMPARs and NMDARs. Consistent with the results of paired recordings, the eIPSCs showed a typical paired-pulse depression in the wild-type mice, whereas the paired-pulse depression was abolished in the mutant mice (Figure 6B2). This data suggests that the calcium-dependent release of GABA was compromised in the mutants. We next studied the properties of eIPSCs under different calcium and magnesium ratios in the extracellular solution (Silver et al., 2003). VM analysis was performed based on the methods described previously (Silver, 2003). As shown in Figures 5C2,D2, the change of extracellular calcium and magnesium ratios did not induce significant changes in the input resistance (Rin) of the recorded cells. The V-M plot of eIPSCs in the wild-type mice showed a feature that was consistent with the high release probability (Pr) synapses: when the $\mathrm{Pr}$ was low (e.g., at $0.5 / 5 \mathrm{mM} \mathrm{Ca}^{2+} / \mathrm{Mg}^{2+}$ ), the trial to trial variance of eIPSC amplitude was low; when the Pr was moderate (at $1.25 / 3$ or $2 / 2 \mathrm{mM} \mathrm{Ca}{ }^{2+} / \mathrm{Mg}^{2+}$ ), the trial to trial variability was high; when the $\operatorname{Pr}$ was high (at $5 / 0.5 \mathrm{mM} \mathrm{Ca}{ }^{2+} / \mathrm{Mg}^{2+}$ ), almost all sites released GABA after every stimulus and the eIPSC amplitude variance was low (Figure 5C). Therefore, the V-M plot of GABA release in the wild-type neurons showed a typical parabolic plot $\mathrm{y}=\mathrm{Ax}-\mathrm{Bx}^{2}$ (1). The following three equations were used to calculate the average synaptic parameters: quantal content $(\mathrm{Qw})=\mathrm{A} /\left(1+\mathrm{CV}_{1}^{2}\right)(\mathrm{CV}$, coefficient of variance $)$ (2); release probability of the eIPSCs $\mathrm{P}_{\mathrm{rw}}=\mathrm{X}(\mathrm{B} / \mathrm{A})\left(1+\mathrm{CV}_{1}{ }^{2}\right)$ (3); and number of minimum release site $(\mathrm{N} / \mathrm{min})=1 / \mathrm{B}$ (4). The eIPSCs of wild-type mice were estimated to have a $\mathrm{Qw}$ of $14.3 \pm 2.5 \mathrm{pA}$, with $\mathrm{N} / \mathrm{min}$ of $10 \pm 2$. The $\mathrm{P}_{\mathrm{rw}}$ varies from $0.1 \pm 0.2$ at $0.5 / 5 \mathrm{mM} \mathrm{Ca}^{2+} / \mathrm{Mg}^{2+}$ to $1.0 \pm 0.2$ at $5 / 0.5 \mathrm{mM}$ $\mathrm{Ca}^{2+} / \mathrm{Mg}^{2+}$. Next, we studied the eIPSCs in $\mathrm{KIV}^{-/-}$mice under similar conditions and performed $\mathrm{V}-\mathrm{M}$ analysis. As shown in Figure 5D, eIPSCs in mutant neurons did not show the typical $\mathrm{V}-\mathrm{M}$ relationship that can be plotted using a typical parabolic plot. In contrast, the $\mathrm{V}-\mathrm{M}$ relationship in mutants was linear, which indicated that the Pr of these synapses was always low $(<0.3)$, with a significantly smaller Qw of $3.8 \pm 1.5 \mathrm{pA}$ ( $p<0.05$ vs. wild-type mice). The amplitudes of eIPSCs in the four different $\mathrm{Ca}^{2+} / \mathrm{Mg}^{2+}$ concentrations also showed statistical significant differences at higher $\mathrm{Ca}^{2+}$ concentrations $(p=0.3$, $0.5,0.04$, and 0.01 , respectively) between wild-type (17 \pm 2 , $45 \pm 7,91 \pm 11$, and $131 \pm 13 \mathrm{pA}$, respectively) and KIV group $(11 \pm 3,36 \pm 4,40 \pm 3$, and $51 \pm 5 \mathrm{pA}$, respectively). The results of the V-M analysis indicate that inhibitory synaptic transmission is compromised in $\mathrm{KIV}^{-/-}$mice, with significantly lower quantal content and release probabilities. These findings suggest that activity-driven BDNF expression fine-tunes the strength of intracortical GABAergic transmissions by remodeling of presynaptic calcium-dependent vesicle release features of GABAergic synapses. Thus, activity-driven expression of BDNF is required 

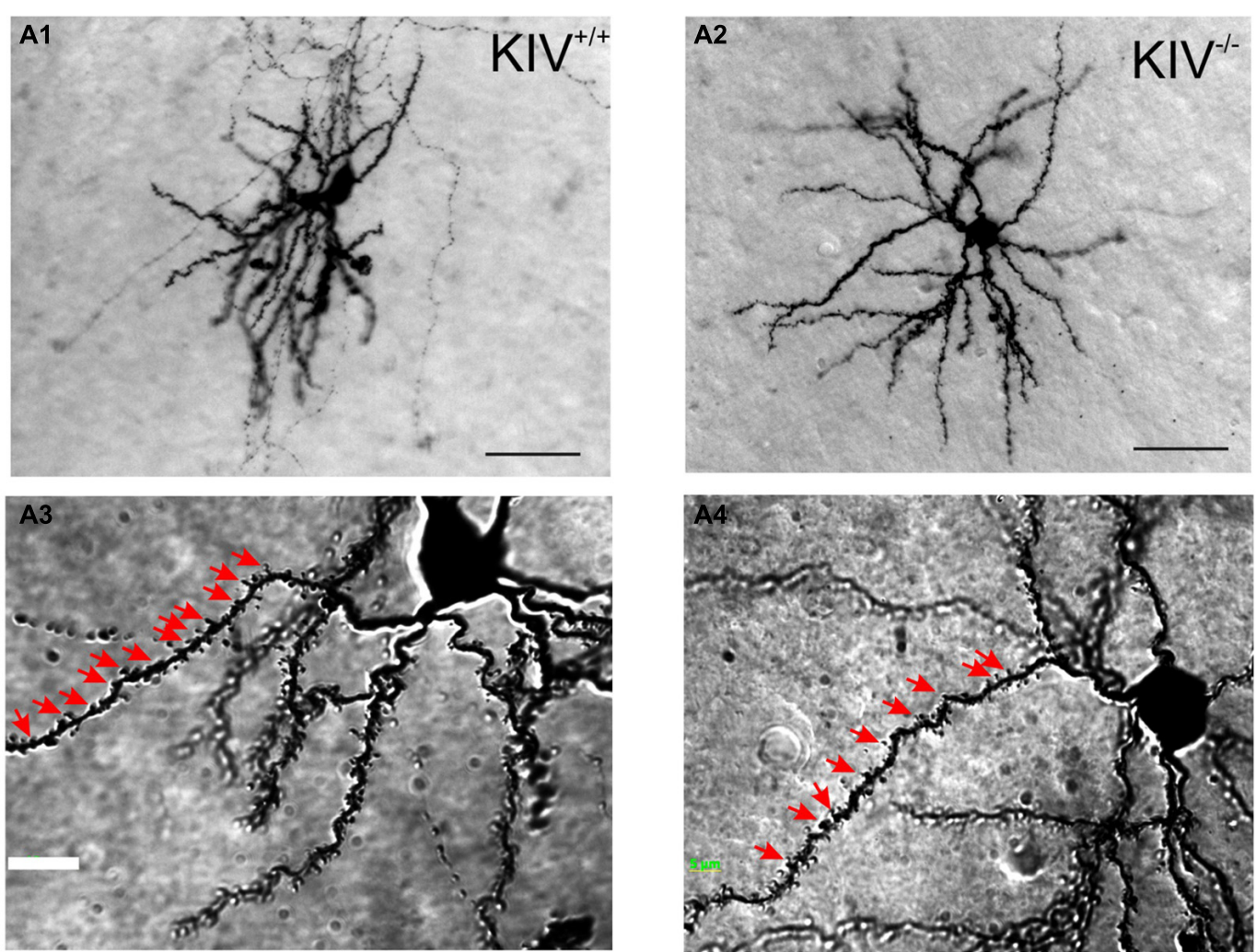

B1

B2

B3

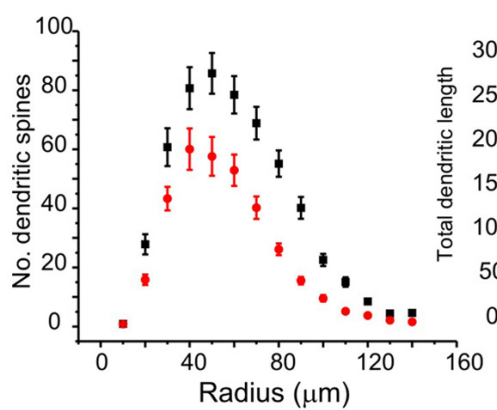

B4

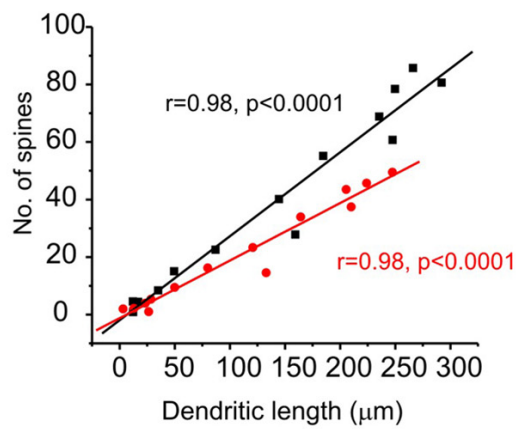

FIGURE 2 | Altered dendritic morphology in $\mathrm{KIV}^{-/-}$mice. (A)

Photomicrograph of a pair of neurobiotin labeled spiny stellate cells from littermate wild-type $(A 1, A 3)$ and $\mathrm{KIV}^{-1-}$ mice $(\mathrm{A} 2, \mathrm{~A} 4)$, respectively. Scale bar in $(A 1, A 2) 10 \mu \mathrm{m}$; Scale bar in $(A 3, A 4) 2 \mu \mathrm{m}$. White arrows in $(A 3, A 4)$ dendritic spines. (B) Sholl analysis was performed to compare the distribution of

dendritic spines (B1), the distribution of total dendritic length (B2), as well as the no. of intersections (B3) along different dendritic radiums from the soma. (B4) The average no. of dendritic spines was plotted against its dendritic length in wild-type mice (black squares) and $\mathrm{KIV}^{-} /^{-}$mice (red circles). (B5) the spine density in wild-type vs. $\mathrm{KIV}^{-} /^{-}$mice was plotted against the dendritic radius from the soma. $n=25$ and 19 wild-type and mutant spiny stellate cells, respectively. 


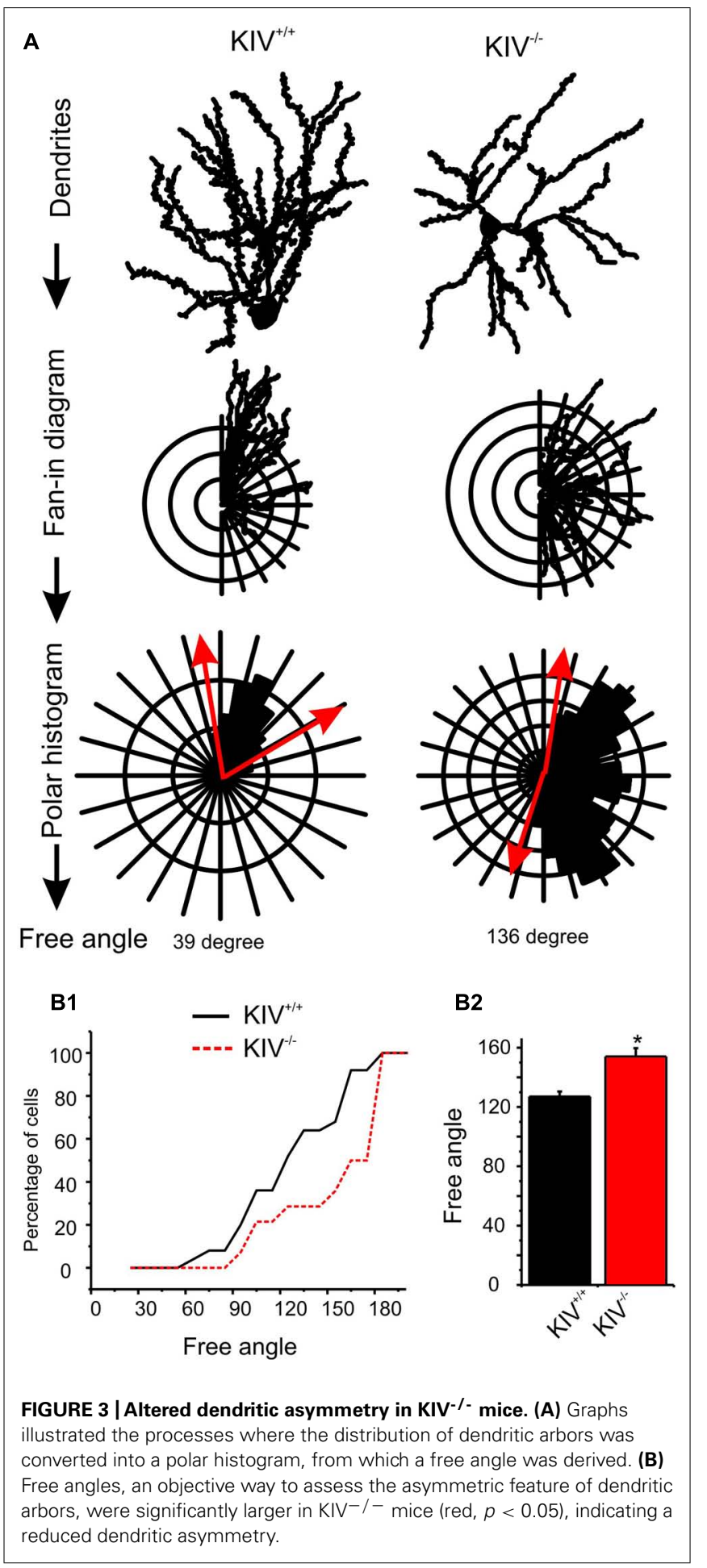

for maintaining the presynaptic features of GABAergic synapses, and the basal level of BDNF is insufficient to maintain these features.

\section{GLUTAMATERGIC TRANSMISSION}

Intracortical unitary EPSCs between wild-type spiny stellate cells did not show the type of paired-pulse depression as seen in uIPSCs
(Figure 6A). Next, eEPSCs were induced by placing an extracellular tungsten stimulating electrode near the recorded cells $(<100 \mu \mathrm{m})$, in the presence of a cocktail solution containing picrotoxin $(100 \mu \mathrm{M})$ and a low concentration of NBQX $(0.1 \mu \mathrm{M})$ to partially block AMPARs and prevent epileptiform activity in the tissue (Kumar and Huguenard, 2001). Similar to uEPSCs, the eEPSCs did not show strong paired-pulse depression in either mutant or wild-type mice (Figure 6A3). The CV of the amplitudes of eEPSCs also remained similar between wild-type and $\mathrm{KIV}^{-/-}$mice (Figure 6A4). To further examine the properties of intracortical glutamate transmission, we studied the properties of eEPSCs under different calcium and magnesium ratios in the extracellular solution (Silver etal., 2003). As shown in Figures 6B2,C2, the change of extracellular calcium and magnesium ratios did not induce significant changes in the input resistance (Rin) of the recorded cells. eEPSC VM plot showed a linear regression with similar slopes in the wild-type and mutant neurons (Figure 6). This indicates that the release probability $(\mathrm{Pr})$ for these synapses was restricted to the lower range $(<0.3)$, therefore a linear fit was appropriate: $\mathrm{Y}=\mathrm{Ax}(5)$. We next estimated the $\mathrm{Qw}$ using equation (2): $\mathrm{Q}_{\mathrm{W}}=\mathrm{A}\left(1+\mathrm{CV}^{2}\right) \cdot \mathrm{Q}_{\mathrm{w}}$ of the $\mathrm{KIV}^{-/-}$mice $(7.2 \pm 1.0)$ was similar to that of wild-type mice $(7.4 \pm 0.8, p>0.3)$. The amplitudes of evoked EPSCs in the four different $\mathrm{Ca}^{2+} / \mathrm{Mg}^{2+}$ concentrations showed no statistical significant differences $(p=0.8,0.4,0.6$, and 0.3 , respectively) between wild-type $(10 \pm 2,11 \pm 1.5,37 \pm 7$, and $78 \pm 20 \mathrm{pA}$, respectively) and KIV group $(9 \pm 2,20 \pm 3,29 \pm 4$, and $36 \pm 5 \mathrm{pA}$, respectively). Our results indicated that the properties of glutamatergic EPSCs induced by local electrical stimulation were similar between the wild-type and $\mathrm{KIV}^{-} /^{-}$mice. These findings support the idea that excitatory transmission in the mutant is similar to the wild-type mice. Therefore, activity-driven BDNF is not required for the development/maintenance of the properties of glutamate synapses, and a basal level of BDNF appears to be sufficient to achieve this role.

\section{DISCUSSION}

The output of neural circuits are fine-tuned according to different brain states (Hasenstaub etal., 2007), which underlies cognitive function of the brain. Abnormal balance of excitation and inhibitions underlies neurodevelopmental disorders and epilepsy (Yizhar et al., 2011; Paz et al., 2013). Understanding the relationship in how activity and BDNF interacts to generate circuit specific modulation and control cortical plasticity is imperative. Using the $\mathrm{KIV}^{-/-}$-GAD67-GFP ${ }^{+/-}$line, allowing the visualization of GABAergic interneurons, we have previously addressed the effects of the $\mathrm{KIV}^{-/-}$line on whisker-trimming induced plasticity of GABAergic synapses (Jiao et al., 2011). However, further investigations of the consequences of disrupting of activity-driven BDNF expression on the maturation of the entire neuronal network in vivo are necessary. This type of work has never been done for the $\mathrm{KIV}^{-/-}$mutants. To our knowledge, this type of work has not been done for other mouse models of reduced BDNF (e.g., heterozygotes).

Our first major finding is that activity-driven BDNF expression in the barrel cortex is important for the maturation and/or maintenance of dendritic arborizations, especially spine densities. Although it is well established that BDNF contributes to the 


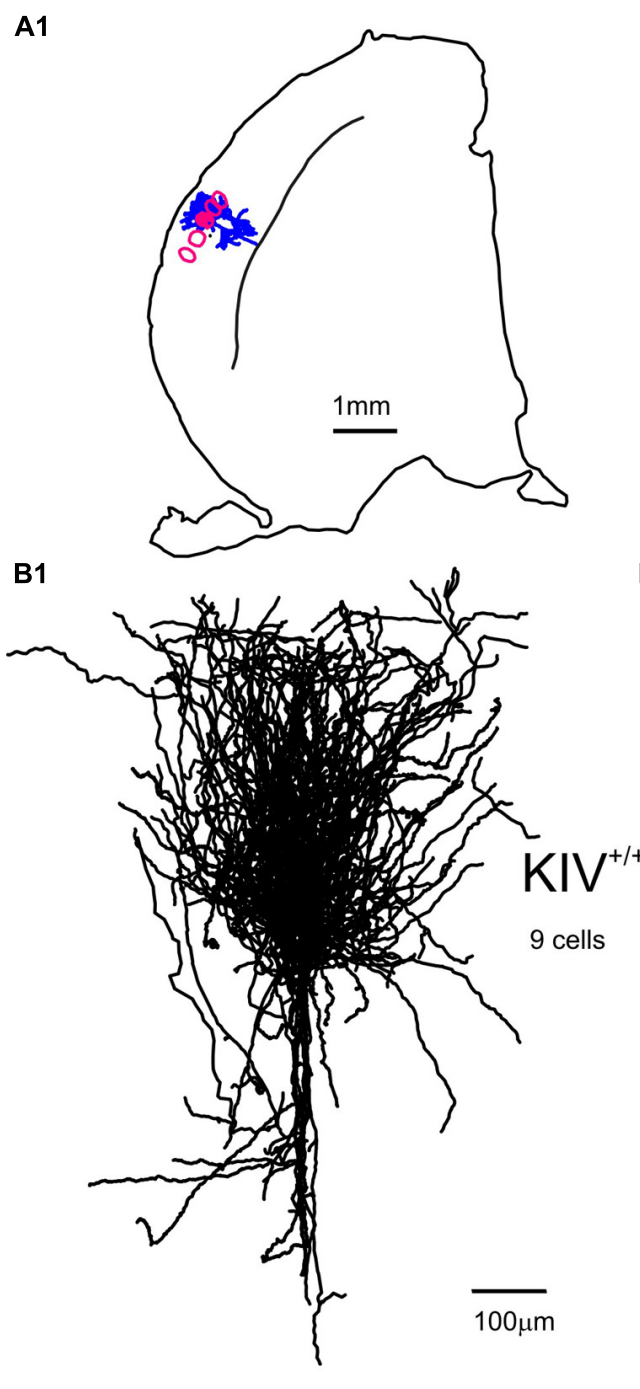

C1

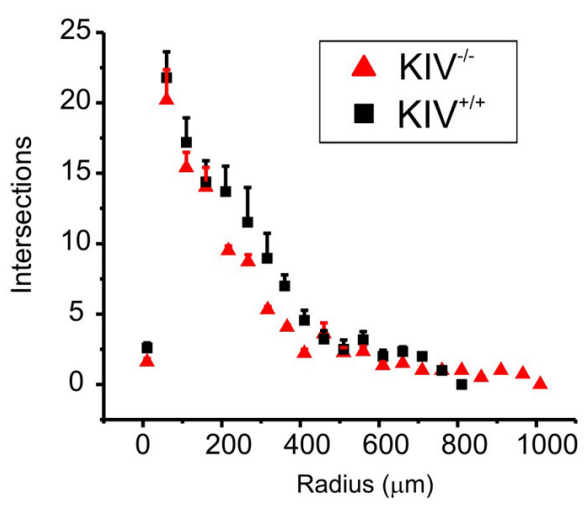

A2

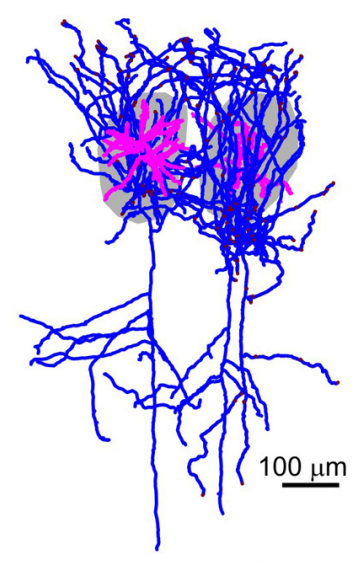

B2
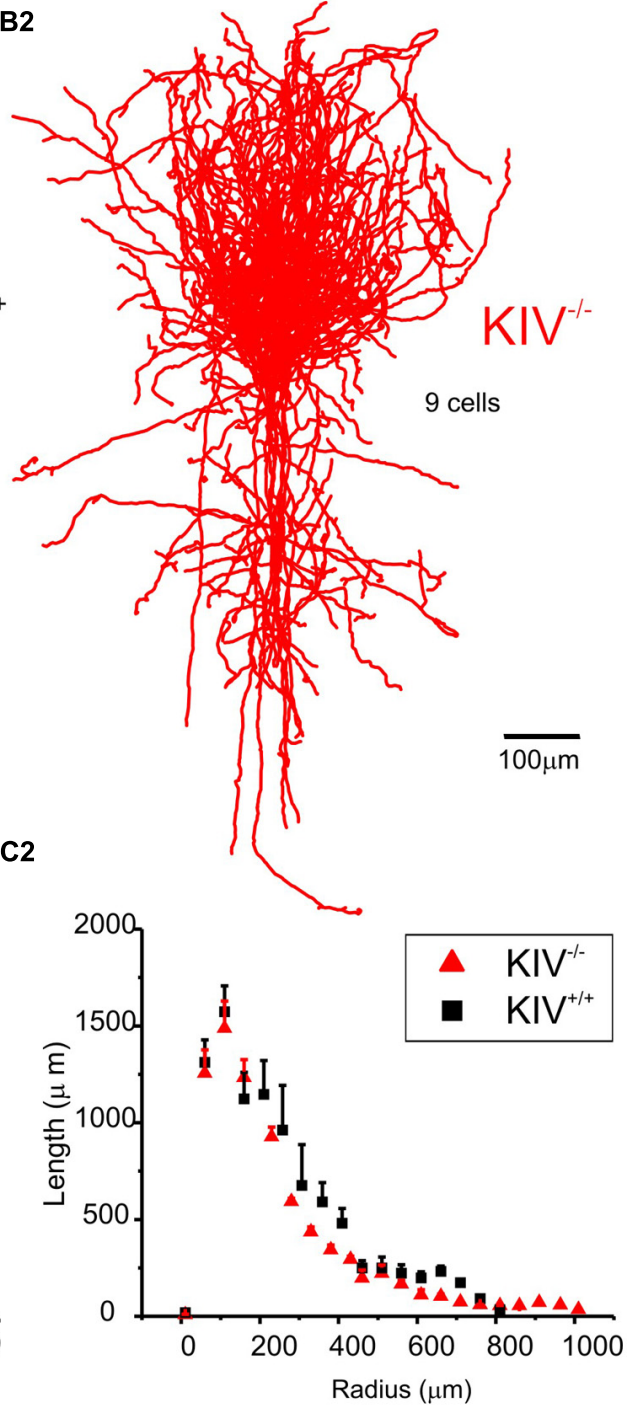

FIGURE 4 | Axonal morphology was unaltered in $\mathrm{KIV}^{-/-}$mice. (A) An example of a pair of reconstructed wild-type spiny stellate cells, located in neighboring barrels (grey areas in A2 and red contour in A1). Note the typical distribution of axonal arbors (blue) within layer IV barrels with projections toward layer II/III, and downward projections toward the white matter. Dendrites (magenta) are largely confined within a single barrel. (B)
Reconstructed axonal arbors from 9 pairs of wild-type (B1, black) and littermate mutant neurons (B2, red) were superimposed at the soma location. (C) Sholl analysis was performed to compare the distribution of no. of intersections (C1), and the distribution of total axonal length (C2) along different radius from the soma in 21 wild-type and 10 mutant neurons, respectively. No statistical differences between WT and KIV mice. 
Table 2 | Structural analysis of axonal arbors between wild-type and $\mathrm{KIV}^{-/-}$spiny stellate cells.

\begin{tabular}{|c|c|c|c|c|c|c|}
\hline & Nodes & Ends & $\begin{array}{l}\text { Length } \\
(\mu \mathrm{m})\end{array}$ & $\begin{array}{l}\text { Mean length } \\
(\mu \mathrm{m})\end{array}$ & $\begin{array}{l}\text { Surface } \\
\left(\mu \mathrm{m}^{2}\right)\end{array}$ & $\begin{array}{l}\text { Volume } \\
\left(\mu \mathbf{m}^{3}\right)\end{array}$ \\
\hline $\mathrm{KIV}^{+/+}(n=9)$ & $52.3 \pm 8.7$ & $54.0 \pm 8.9$ & $6174.4 \pm 1013$ & $6119.7 \pm 1045$ & $6270.3 \pm 1314$ & $608.8 \pm 143$ \\
\hline $\mathrm{KIV}^{-/-}(n=9)$ & $58.1 \pm 6.8$ & $60.2 \pm 6.8$ & $6944.0 \pm 834$ & $6435.7 \pm 627$ & $6516.4 \pm 946$ & $554.2 \pm 149$ \\
\hline$p$ value & 1.0 & 0.9 & 0.5 & 0.8 & 0.8 & 0.7 \\
\hline
\end{tabular}

A1

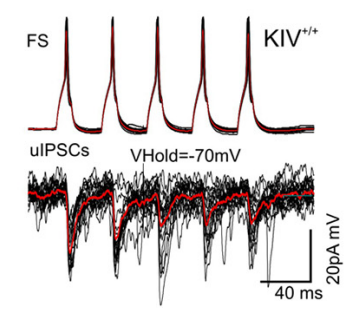

C1

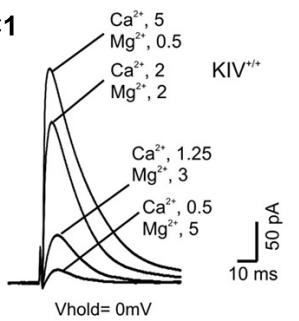

D1

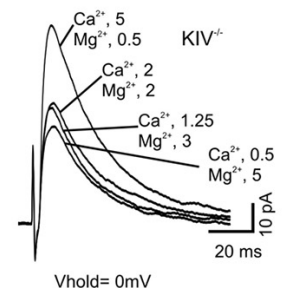

A2

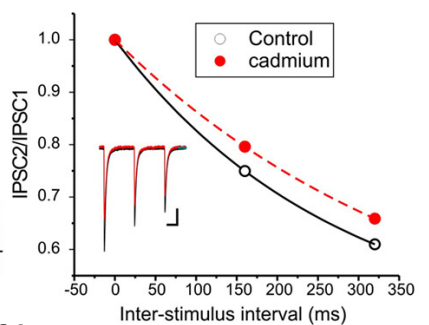

C2

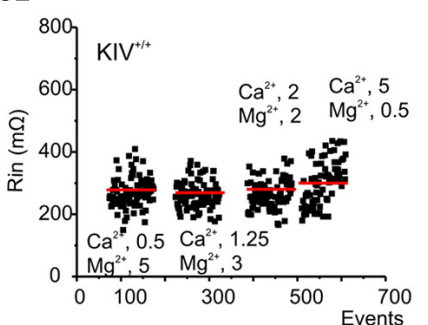

D2

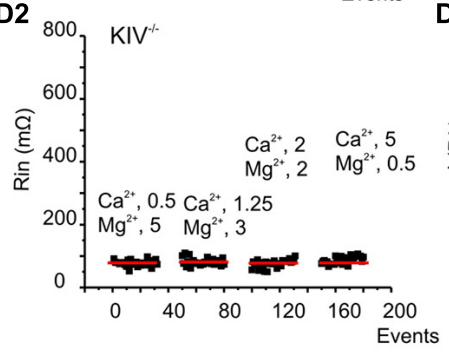

B1

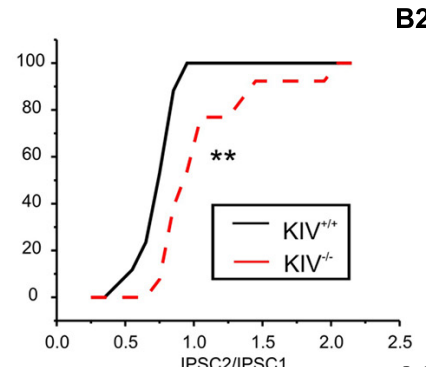

B2

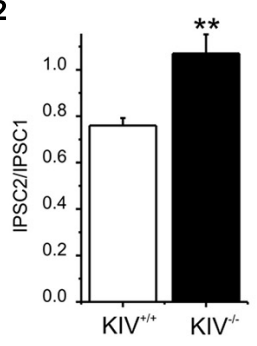

C3

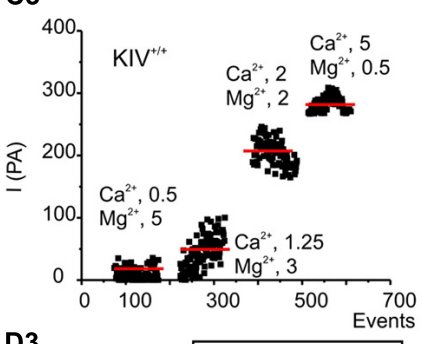

D3

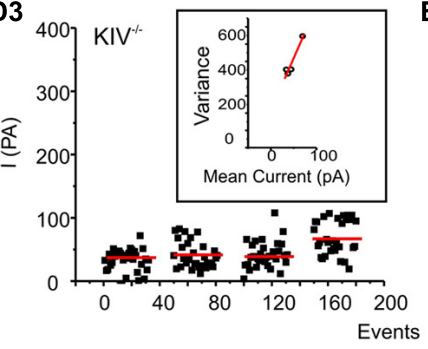

C4

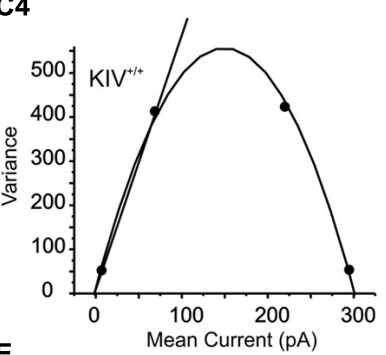

E

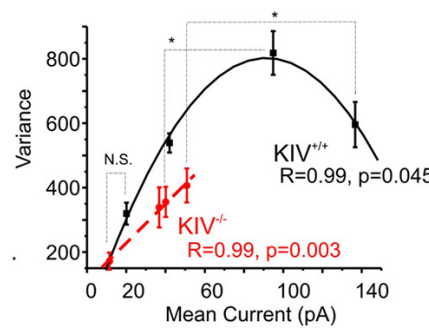

FIGURE 5 | Altered presynaptic GABAergic transmission in $\mathrm{KIV}^{-/-}$mice. (A) Paired recordings from a pair of synaptic connected cells in layer IV of a wild-type mouse. Repetitive action potentials (top) in a FS cell induced GABAergic uIPSCs (bottom) in the post-synaptic spiny stellate cell (A1). The averaged uIPSCs (red trace in the bottom) showed a short-term depression, which was reduced by calcium channel blocker cadmium (100 $\mu$ M, A2). (B) The characteristic paired-pulse depression of eIPSCs in spiny stellate cells of wild-type mice was abolished in $\mathrm{KIV}^{-/-}$mice. $n=8$ cells in each group.
(C,D) IPSCs were evoked in the presence of different extracellular $\mathrm{Ca}^{2+} / \mathrm{Mg}^{2+}$ ratios $(\mathrm{C} 1, \mathrm{D} 1)$ in wild-type $(\mathbf{C}, n=8)$ and $\mathrm{KIV}^{-/-}$mice $(\mathbf{D}, n=8)$. The input resistance $(\mathrm{C} 2, \mathrm{D} 2)$, and amplitude $(\mathrm{C} 3, \mathrm{D} 3)$ of each evoked IPSC event was plotted against experimental time. (C4,D4) V-M analysis of the same experiments of $\mathrm{C} 1, \mathrm{D} 1$. (E) The $\mathrm{V}-\mathrm{M}$ analysis of all wild-type mice (black squares) and $\mathrm{KIV}^{-1-}$ mice (red circles), statistical analysis were performed between amplitude of eIPSCs evoked in the same conditions. ${ }^{*} p<0.05$; ${ }^{* *} p<0.01$. sculpting of dendrites and synapses (Horch et al., 1999; Horch and Katz, 2002; Gorski et al., 2003; Jin et al., 2003; English et al., 2012), the range and source of BDNF signaling underlying these functions is unclear. Data from our studies indicates that sensory activity-dependent synthesis of BDNF accounts for approximately $2 / 3$ of the total BDNF within the barrel cortex (Jiao et al., 2011). Sensory experience drives the stabilization of new spines in the subclasses of cortical neurons and promotes the formation of new synapses (Holtmaat et al., 2008). In the BDNF heterozygote mouse,
BDNF expression is reduced to less than half of wild-type mouse. However, both the spine density, spine morphology, and synaptic vesicle distribution is indistinguishable from wild-type controls (Genoud et al., 2004). In contrast, in the $b d n f-K I V$ mice, the reduction in BDNF protein is similar to the BDNF heterozygote mouse, yet, both spines are severely reduced (Figure 2). More importantly, the dendritic asymmetry, a feature highly unique to the spiny stellate cells (Staiger et al., 2004; Egger et al., 2008), were shown to be regulated via experience-dependent process (Fox and 


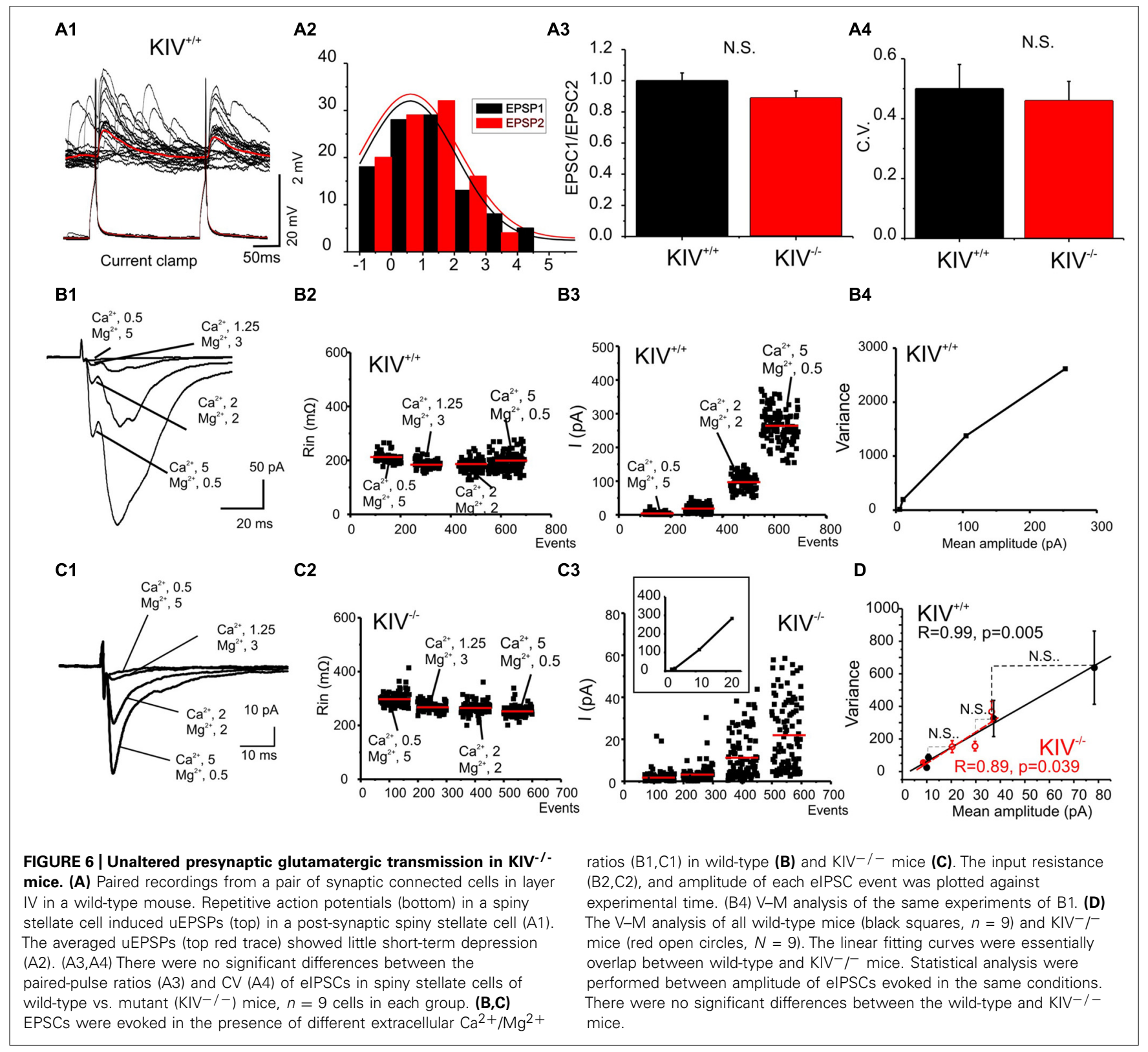

Wong, 2005), as was indeed reduced in the $\mathrm{KIV}^{-/-}$mice. Thus, our data described here indicates, for the first time, that constitutive BDNF is insufficient to maintain the spine density and normal dendritic arborizations in the sensory cortex, and activitydriven BDNF is responsible for the stabilization of dendritic spines.

In contrast to the dendrites, activity-driven BDNF expression is NOT required for the maturation and/or maintenance of intracortical glutamatergic axonal arbors in vivo. Previous studies conclude that BDNF's modulation occurs both within axonal and dendritic compartments (Cohen-Cory and Fraser, 1995; Cabelli et al., 1997), and is mediated by protein synthesis in both compartments as well (Kang and Schuman, 1996). BDNF is essential for the outgrowth and activity-dependent remodeling of axonal arbors in vivo (Hu et al., 2005; Jeanneteau et al., 2010). However, it is unclear whether this requires constitutive and/or activity-driven BDNF. The axonal arbors of layer IV spiny stellate cells shows stereotyped organization in a manner that facilitates thalamocortical relay onto layer II/III cells (Staiger et al., 2004; Egger et al., 2008). Studies have shown that the intracortical axonal branches in layer $2 / 3$ are modulated by sensory manipulations (Bruno et al., 2009). Our data suggests that there are no significant differences in axonal arbors of layer IV cells between wild-type mice and mice lacking activity-driven BDNF, even though the dendritic arbors showed significant differences in the same neuron. Thus, we propose that the activity-dependent remodeling of axonal arbors is NOT mediated by activity-driven BDNF expression. It appears that the basal level of BDNF is adequate in the development and/or maintenance of axonal arbors of adult spiny stellate cells. 
Our third and perhaps most surprising conclusion is related to the subcellular specificity of the effects of activity-driven BDNF expression within layer IV. (1) presynaptic GABAergic transmissions, but not glutamatergic transmissions, are affected in $\mathrm{KIV}^{-/-}$mice (Figures 5 and 6). (2) Within GABAergic synapses, the effects of mutation selectively affect the synaptic transmission mediated by presynaptic calcium-dependent properties (release probability, no. of release sites, and quanta content). Moreover, our previous results showed that the disruption of activity-driven BDNF expression prevented sensory deprivation-induced barrelspecific attenuations of GABAergic transmissions. In the $\mathrm{KIV}^{-/-}$ mice, whisker-trimming induced plasticity in inhibitory synaptic transmissions was entirely abolished (Jiao et al., 2011). In addition, there are no significant differences in the properties of miniature IPSCs between the wild-type and $\mathrm{KIV}^{-/-}$mice (Jiao et al., 2011). The strong effects on dendritic spines and GABAergic transmissions vs. lack of effects on axonal arbors and glutamate transmissions appear to be paradoxical: the spine is usually associated with the establishment of glutamatergic synapses. However, it has been reported that GABAergic synapses formulate at the dendritic spines of spiny stellate cells (Knott et al., 2002). We further hypothesize that dendritic spines are subdivided into GABAergic containing and putative glutamatergic spines. Our results indicate that these GABAergic containing dendritic spines require expression of activity-driven BDNF. Our data should not be interpreted as lack of any changes associated with glutamatergic synapses. In fact, both our current data (Figures 6B1 vs. 6C1) and earlier data (Jiao et al., 2011), demonstrated a reduction of glutamatergic synaptic conductances in the KIV mice. It is remarkable that a significant removal of BDNF (about $2 / 3$ of reduction in total BDNF is mediated via activity-dependent process), only produced negligible effects on presynaptic properties of intracortical glutamatergic transmissions, but severely changed the presynaptic but not post-synaptic GABAergic transmissions (this study), and completely abolished whisker-trimming induced plasticity of the GABAergic network in vivo (Jiao et al., 2011). The network consequences of such an effect are intriguing. While the function of intracortical glutamatergic transmissions between layer IV spiny cells is to relay sensory information onto layer II/III (Shepherd and Svoboda, 2005; Bruno and Sakmann, 2006), the function of intracortical GABAergic transmissions is to generate feed-forward inhibition (Bruno and Simons, 2002; Swadlow, 2003; Sun et al., 2006), which provides gain control over receptive field properties. Activity-driven BDNF selectively targets the feed-forward inhibition, but spares the glutamatergic transmission and wiring, which is fundamentally important for the sensory transmission.

Although BDNF has been postulated to play critical roles in neuronal circuit development and plasticity (Greenberg etal., 2009; Deinhardt and Chao, 2013), here we demonstrated a high degree of selectivity of activity regulated BDNF expression mediated effects on individual neurons within a functional network in vivo. The contrasting effects of genetic removal of activitydriven BDNF on dendrites vs. axonal arbors, and GABAergic vs. glutamatergic synapses, demonstrate a highly specific effect of neurotrophin in the activity-dependent sculpting of neural circuits. We postulate that the role of activity-dependent BDNF is to modulate the computational ability of circuits that relate to the gain control (i.e., feed-forward inhibition); whereas the basic wiring of circuits relevant to the sensory pathway is spared. Gain control modulation within cortical circuits has broad impact on cognitive processing attention related behavior (Kerlin et al., 2010). Cognitive behavior and mode is determined by brain states. Thus the studying of circuit alteration by endogenous BDNF provides insights into the cellular and molecular mechanisms of diseases mediated by BDNF. These results raise a number of interesting questions regarding the need to uncover the precise subcellular and molecular mechanisms of such an action. These results also shed light on the potential neural mechanisms underlying cognitive impairments within the sensory system.

\section{ACKNOWLEDGMENTS}

Research was supported by the National Institute of Neurological Disorders and Stroke of the National Institutes of Health under Award Number R15NS081628. We thank Dr. Bai Lu for sending us the BDNF-KIV mice and Dr. Kevin Jones for discussions.

\section{REFERENCES}

Agmon, A., and Connors, B. W. (1991). Thalamocortical responses of mouse somatosensory (barrel) cortex in vitro. Neuroscience 41, 365-379. doi: 10.1016/0306-4522(91)90333-J

Aid, T., Kazantseva, A., Piirsoo, M., Palm, K., and Timmusk, T. (2007). Mouse and rat BDNF gene structure and expression revisited. J. Neurosci. Res. 85, 525-535. doi: 10.1002/jnr.21139

Brecht, M., and Sakmann, B. (2002). Dynamic representation of whisker deflection by synaptic potentials in spiny stellate and pyramidal cells in the barrels and septa of layer 4 rat somatosensory cortex. J. Physiol. 543, 49-70. doi: 10.1113/jphysiol.2002.018465

Bruno, R. M., Hahn, T. T., Wallace, D. J., de Kock, C. P., and Sakmann, B. (2009). Sensory experience alters specific branches of individual corticocortical axons during development. J. Neurosci. 29, 3172-3181. doi: 10.1523/JNEUROSCI.591108.2009

Bruno, R. M., and Sakmann, B. (2006). Cortex is driven by weak but synchronously active thalamocortical synapses. Science 312, 1622-1627. doi: 10.1126/science. 1124593

Bruno, R. M., and Simons, D. J. (2002). Feedforward mechanisms of excitatory and inhibitory cortical receptive fields. J. Neurosci. 22, 10966-10975.

Cabelli, R. J., Shelton, D. L., Segal, R. A., and Shatz, C. J. (1997). Blockade of endogenous ligands of trkB inhibits formation of ocular dominance columns. Neuron 19, 63-76. doi: 10.1016/S0896-6273(00)80348-7

Caylak, E. (2012). Biochemical and genetic analyses of childhood attention deficit/hyperactivity disorder. Am. J. Med. Genet. B Neuropsychiatr. Genet. 159B, 613-627. doi: 10.1002/ajmg.b.32077

Chang, Q., Khare, G., Dani, V., Nelson, S., and Jaenisch, R. (2006). The disease progression of Mecp2 mutant mice is affected by the level of BDNF expression. Neuron 49, 341-348. doi: 10.1016/j.neuron.2005.12.027

Cohen-Cory, S. (1999). BDNF modulates, but does not mediate, activity-dependent branching and remodeling of optic axon arbors in vivo. J. Neurosci. 19, 999610003.

Cohen-Cory, S., and Fraser, S. E. (1995). Effects of brain-derived neurotrophic factor on optic axon branching and remodelling in vivo. Nature 378, 192-196. doi: $10.1038 / 378192 \mathrm{a} 0$

Deinhardt, K., and Chao, M. V. (2013). Shaping neurons: long and short range effects of mature and proBDNF signalling upon neuronal structure. Neuropharmacology 76(Pt C), 603-609. doi: 10.1016/j.neuropharm.2013.04.054

DiGregorio, D. A., Nusser, Z., and Silver, R. A. (2002). Spillover of glutamate onto synaptic AMPA receptors enhances fast transmission at a cerebellar synapse. Neuron 35, 521-533. doi: 10.1016/S0896-6273(02)00787-0

Durany, N., and Thome, J. (2004). Neurotrophic factors and the pathophysiology of schizophrenic psychoses. Eur. Psychiatry 19, 326-337. doi: 10.1016/j.eurpsy.2004.06.020 
Egger, V., Nevian, T., and Bruno, R. M. (2008). Subcolumnar dendritic and axonal organization of spiny stellate and star pyramid neurons within a barrel in rat somatosensory cortex. Cereb. Cortex 18, 876-889. doi: 10.1093/cercor/bhm126

English, C. N., Vigers, A. J., and Jones, K. R. (2012). Genetic evidence that brain-derived neurotrophic factor mediates competitive interactions between individual cortical neurons. Proc. Natl. Acad. Sci. U.S.A. 109, 19456-19461. doi 10.1073/pnas.1206492109

Feldman, D. E., and Brecht, M. (2005). Map plasticity in somatosensory cortex. Science 310, 810-815. doi: 10.1126/science.1115807

Feldman, D. E., Nicoll, R. A., and Malenka, R. C. (1999). Synaptic plasticity at thalamocortical synapses in developing rat somatosensory cortex: LTP, LTD, and silent synapses. J. Neurobiol. 41, 92-101. doi: 10.1002/(SICI)10974695(199910)41:1<92::AID-NEU12>3.0.CO;2-U

Feldmeyer, D., Brecht, M., Helmchen, F., Petersen, C. C., Poulet, J. F., Staiger J. F., et al. (2013). Barrel cortex function. Prog. Neurobiol. 103, 3-27. doi 10.1016/j.pneurobio.2012.11.002

Feldmeyer, D., Egger, V., Lubke, J., and Sakmann, B. (1999). Reliable synaptic connections between pairs of excitatory layer 4 neurones within a single 'barrel' of developing rat somatosensory cortex. J. Physiol. 521(Pt 1), 169-190. doi: 10.1111/j.1469-7793.1999.00169.x

Fox, K., and Wong, R. O. (2005). A comparison of experience-dependent plasticity in the visual and somatosensory systems. Neuron 48, 465-477. doi: 10.1016/j.neuron.2005.10.013

Genoud, C., Knott, G. W., Sakata, K., Lu, B., and Welker, E. (2004). Altered synapse formation in the adult somatosensory cortex of brain-derived neurotrophic factor heterozygote mice. J. Neurosci. 24, 2394-2400. doi: 10.1523/JNEUROSCI.404003.2004

Gorski, J. A., Zeiler, S. R., Tamowski, S., and Jones, K. R. (2003). Brain-derived neurotrophic factor is required for the maintenance of cortical dendrites. J. Neurosci. $23,6856-6865$.

Greenberg, M. E., Xu, B., Lu, B., and Hempstead, B. L. (2009). New insights in the biology of BDNF synthesis and release: implications in CNS function. J. Neurosci. 29, 12764-12767. doi: 10.1523/JNEUROSCI.3566-09.2009

Hanck, D. A., and Sheets, M. F. (1992). Extracellular divalent and trivalent cation effects on sodium current kinetics in single canine cardiac Purkinje cells. J. Physiol. 454, 267-298.

Hasenstaub, A., Sachdev, R. N., and McCormick, D. A. (2007). State changes rapidly modulate cortical neuronal responsiveness. J. Neurosci. 27, 9607-9622. doi: 10.1523/JNEUROSCI.2184-07.2007

Holtmaat, A., De Paola, V., Wilbrecht, L., and Knott, G. W. (2008) Imaging of experience-dependent structural plasticity in the mouse neocortex in vivo. Behav. Brain Res. 192, 20-25. doi: 10.1016/j.bbr.2008. 04.005

Holtmaat, A., Wilbrecht, L., Knott, G. W., Welker, E., and Svoboda, K. (2006). Experience-dependent and cell-type-specific spine growth in the neocortex Nature 441, 979-983. doi: 10.1038/nature04783

Horch, H. W. (2004). Local effects of BDNF on dendritic growth. Rev. Neurosci. 15, 117-129. doi: 10.1515/REVNEURO.2004.15.2.117

Horch, H. W., and Katz, L. C. (2002). BDNF release from single cells elicits local dendritic growth in nearby neurons. Nat. Neurosci. 5, 1177-1184. doi: 10.1038/nn927

Horch, H. W., Kruttgen, A., Portbury, S. D., and Katz, L. C. (1999). Destabilization of cortical dendrites and spines by BDNF. Neuron 23, 353-364. doi: 10.1016/S08966273(00)80785-0

Hu, B., Nikolakopoulou, A. M., and Cohen-Cory, S. (2005). BDNF stabilizes synapses and maintains the structural complexity of optic axons in vivo. Development 132, 4285-4298. doi: 10.1242/dev.02017

Jeanneteau, F., Deinhardt, K., Miyoshi, G., Bennett, A. M., and Chao, M. V. (2010). The MAP kinase phosphatase MKP-1 regulates BDNFinduced axon branching. Nat. Neurosci. 13, 1373-1379. doi: 10.1038/ nn. 2655

Jiao, Y., Zhang, Z., Zhang, C., Wang, X., Sakata, K., Lu, B., et al. (2011). A key mechanism underlying sensory experience-dependent maturation of neocortical GABAergic circuits in vivo. Proc. Natl. Acad. Sci. U.S.A. 108, 12131-12136. doi 10.1073/pnas.1105296108

Jin, X., Hu, H., Mathers, P. H., and Agmon, A. (2003). Brain-derived neurotrophic factor mediates activity-dependent dendritic growth in nonpyramidal neocortical interneurons in developing organotypic cultures. J. Neurosci. 23, 5662-5673.
Kang, H., and Schuman, E. M. (1996). A requirement for local protein synthesis in neurotrophin-induced hippocampal synaptic plasticity. Science 273, 1402-1406 doi: $10.1126 /$ science.273.5280.1402

Kebir, O., Tabbane, K., Sengupta, S., and Joober, R. (2009). Candidate genes and neuropsychological phenotypes in children with ADHD: review of association studies. J. Psychiatry Neurosci. 34, 88-101.

Kerlin, J. R., Shahin, A. J., and Miller, L. M. (2010). Attentional gain control of ongoing cortical speech representations in a "cocktail party." J. Neurosci. 30, 620-628. doi: 10.1523/JNEUROSCI.3631-09.2010

Knott, G. W., Quairiaux, C., Genoud, C., and Welker, E. (2002). Formation of dendritic spines with GABAergic synapses induced by whisker stimulation in adult mice. Neuron 34, 265-273. doi: 10.1016/S0896-6273(02)00663-3

Kumar, S. S., and Huguenard, J. R. (2001). Properties of excitatory synaptic connections mediated by the corpus callosum in the developing rat neocortex. J. Neurophysiol. 86, 2973-2985.

Kumar, S. S., and Huguenard, J. R. (2003). Pathway-specific differences in subunit composition of synaptic NMDA receptors on pyramidal neurons in neocortex. J. Neurosci. 23, 10074-10083.

Lawrence, J. J., and McBain, C. J. (2003). Interneuron diversity series: containing the detonation - feedforward inhibition in the CA3 hippocampus. Trends Neurosci. 26, 631-640. doi: 10.1016/j.tins.2003.09.007

Li, W., and Pozzo-Miller, L. (2014). BDNF deregulation in Rett syndrome. Neuropharmacology 76(Pt C), 737-746. doi: 10.1016/j.neuropharm.2013.03.024

Lom, B., and Cohen-Cory, S. (1999). Brain-derived neurotrophic factor differentially regulates retinal ganglion cell dendritic and axonal arborization in vivo. J. Neurosci. 19, 9928-9938.

Longo, F. M., and Massa, S. M. (2013). Small-molecule modulation of neurotrophin receptors: a strategy for the treatment of neurological disease. Nat. Rev. Drug Discov. 12, 507-525. doi: 10.1038/nrd4024

Lu, B. (2003). BDNF and activity-dependent synaptic modulation. Learn. Mem. 10, 86-98. doi: 10.1101/lm.54603

Lu, B., and Martinowich, K. (2008). Cell biology of BDNF and its relevance to schizophrenia. Novartis Found. Symp. 289, 119-129. doi: 10.1002/9780470751251.ch10

Martinowich, K., Manji, H., and Lu, B. (2007). New insights into BDNF function in depression and anxiety. Nat. Neurosci. 10, 1089-1093. doi: 10.1038/nn1971

Ninan, I. (2014). Synaptic regulation of affective behaviors; role of BDNF. Neuropharmacology 76(Pt C), 684-695. doi: 10.1016/j.neuropharm.2013.04.011

Oleskevich, S., Clements, J., and Walmsley, B. (2000). Release probability modulates short-term plasticity at a rat giant terminal. J. Physiol. 524(Pt 2), 513-523. doi: 10.1111/j.1469-7793.2000.00513.x

Paz, J. T., Davidson, T. J., Frechette, E. S., Delord, B., Parada, I., Peng, K., et al. (2013). Closed-loop optogenetic control of thalamus as a tool for interrupting seizures after cortical injury. Nat. Neurosci. 16, 64-70. doi: 10.1038/nn.3269

Reid, C. A., and Clements, J. D. (1999). Postsynaptic expression of long-term potentiation in the rat dentate gyrus demonstrated by variance-mean analysis. J. Physiol. 518(Pt 1), 121-130. doi: 10.1111/j.1469-7793.1999.0121r.x

Sakata, K., Woo, N. H., Martinowich, K., Greene, J. S., Schloesser, R. J., Shen, L., et al. (2009). Critical role of promoter IV-driven BDNF transcription in GABAergic transmission and synaptic plasticity in the prefrontal cortex. Proc. Natl. Acad. Sci. U.S.A. 106, 5942-5947. doi: 10.1073/pnas.0811431106

Shepherd, G. M., and Svoboda, K. (2005). Laminar and columnar organization of ascending excitatory projections to layer $2 / 3$ pyramidal neurons in rat barrel cortex. J. Neurosci. 25, 5670-5679. doi: 10.1523/JNEUROSCI.1173-05.2005

Silver, R. A. (2003). Estimation of nonuniform quantal parameters with multipleprobability fluctuation analysis: theory, application and limitations. J. Neurosci. Methods 130, 127-141. doi: 10.1016/j.jneumeth.2003.09.030

Silver, R. A., Lubke, J., Sakmann, B., and Feldmeyer, D. (2003). High-probability uniquantal transmission at excitatory synapses in barrel cortex. Science 302, 19811984. doi: 10.1126/science. 1087160

Silver, R. A., Momiyama, A., and Cull-Candy, S. G. (1998). Locus of frequencydependent depression identified with multiple-probability fluctuation analysis at rat climbing fibre-Purkinje cell synapses. J. Physiol. 510(Pt 3), 881-902. doi: 10.1111/j.1469-7793.1998.881bj.x

Staiger, J. F., Flagmeyer, I., Schubert, D., Zilles, K., Kotter, R., and Luhmann, H. J. (2004). Functional diversity of layer IV spiny neurons in rat somatosensory cortex: quantitative morphology of electrophysiologically characterized and biocytin labeled cells. Cereb. Cortex 14, 690-701. doi: 10.1093/cercor/bhh029 
Sun, Q. Q., Huguenard, J. R., and Prince, D. A. (2006). Barrel cortex microcircuits: thalamocortical feedforward inhibition in spiny stellate cells is mediated by a small number of fast-spiking interneurons. J. Neurosci. 26, 1219-1230. doi: 10.1523/JNEUROSCI.4727-04.2006

Swadlow, H. A. (2003). Fast-spike interneurons and feedforward inhibition in awake sensory neocortex. Cereb. Cortex 13, 25-32. doi: 10.1093/cercor/13.1.25

Wong-Riley, M. T., and Welt, C. (1980). Histochemical changes in cytochrome oxidase of cortical barrels after vibrissal removal in neonatal and adult mice. Proc. Natl. Acad. Sci. U.S.A. 77, 2333-2337. doi: 10.1073/pnas.77.4.2333

Xu-Friedman, M. A., and Regehr, W. G. (2000). Probing fundamental aspects of synaptic transmission with strontium. J. Neurosci. 20, 4414-4422.

Yizhar, O., Fenno, L. E., Prigge, M., Schneider, F., Davidson, T. J., O’Shea, D. J., et al. (2011). Neocortical excitation/inhibition balance in information processing and social dysfunction. Nature 477, 171-178. doi: 10.1038/nature10360

Young, A., and Sun, Q. Q. (2009). GABAergic inhibitory interneurons in the posterior piriform cortex of the GAD67-GFP mouse. Cereb. Cortex 19, 3011-3029. doi: $10.1093 /$ cercor/bhp072
Conflict of Interest Statement: The authors declare that the research was conducted in the absence of any commercial or financial relationships that could be construed as a potential conflict of interest.

Received: 27 September 2014; accepted: 21 October 2014; published online: 06 November 2014.

Citation: Sun Q-Q, Zhang Z, Sun J, Nair AS, Petrus DP and Zhang C (2014) Functional and structural specific roles of activity-driven BDNF within circuits formed by single spiny stellate neurons of the barrel cortex. Front. Cell. Neurosci. 8:372. doi: 10.3389/fncel.2014.00372

This article was submitted to the journal Frontiers in Cellular Neuroscience.

Copyright (c) 2014 Sun, Zhang, Sun, Nair, Petrus and Zhang. This is an openaccess article distributed under the terms of the Creative Commons Attribution License (CC BY). The use, distribution or reproduction in other forums is permitted, provided the original author(s) or licensor are credited and that the original publication in this journal is cited, in accordance with accepted academic practice. No use, distribution or reproduction is permitted which does not comply with these terms. 